\title{
Cell Wall Lytic Enzymes And Their Role In Bacteriophages Infection
}

(Literature Review)

\author{
I Putu Sudiarta ${ }^{1}$, Gusti Ngurah Alit Susanta Wirya ${ }^{2}$ \\ ${ }^{1}$ Shinshu University, Matsumoto, Japan \\ ${ }^{2}$ Programstudi Bioteknologi Pertanian, Fakultas Pertanian, Universitas Udayana
}

putu.ueda@yahoo.com

\begin{abstract}
Use of chemical pesticides has been shown to have many negative side effects, such as insecticide resistance and resurgence, outbreak of secondary pests and diseases, disappearance of parasitoid and predator species as well as residual effects on food crops and on the environment. Over the past 60 years both the number of agricultural toxins in the environment and incidence rates of toxin-related diseases has increased dramatically. The most effective way to combat this problem is through the use of natural predators. One of the best examples of this is the use of host specific bacteriophages to control bacterial diseases. The mechanism of infection is a very interesting one. To break through the bacterial cell wall the bacteriopages must produce a range of lytic enzymes. This review will examine and discuss studies of these site specific cell wall lytic enzymes and their roles in the infection of bacteriophages.
\end{abstract}

Key words: Cell wall lytic enzymes, biological control, bacteriophages

\section{INTRODUCTION}

As global populations and food consumption grow rapidly, the amount of productive land available for agriculture is decreasing. As a solution to this problem, in 1992 UNCED (United Nations Conference on Environmental and Development) recommended the adoption of the concept of sustainable development (Djuniadi, 2003). Based on this recommendation, sustainable development must address social, economic, and ecological factors at the local, regional, and global level.
Unfortunately, food production in the decades since the 1940s has increasingly been conducted using methods involving heavy application of chemical pesticides and fertilizers (Erickson 2009). Despite the pest control benefits they provide, chemical pesticides have many negative effects such as insecticide resistance and resurgence, outbreak of secondary pests and diseases, disappearance of parasitoid and predator species, and residual environmental effects. Over the past 60 years both the number of agricultural toxins in the environment and incidence 
rates of toxin-related diseases have increased dramatically. These 'toxicants' are widely distributed in nature and many lack an established NOAEL (no observed adverse effect level) or consensus about their long term health effects (Oates and Cohen, 2009).

One possible way to reduce the volume and frequency of chemical pesticide use in agriculture areas is through the use of natural pest control methods. In natural ecosystems, pests and diseases have enemies, competitors and antagonists such as parasitoids, predators, pathogens and viruses (bacteriophages) (Lacey et al., 2001; Loessner 2005; Susila et al, 2005; Supartha et al, 2005; Sumiartha et al, 2006;). Through organic farming techniques it is possible to harness these naturally existing relationships to balance ecosystem factors and make farming more sustainable.

One way to control diseases caused by bacteria is to utilize bacteriophages, whose mechanisms of infection have been previously studied. Bacteriophage T7 was reported to infect the Escherichia coli cells, with cell wall lytic enzyme gp16 playing a beneficial role during that infection (Moak and Molineux, 2000). Loessner (2005) reviewed the application of bacteriophage endolysins (cell wall lytic enzymes). Endolysins have previously been used in food and in biotechnology for their target specificity. Therefore they offer a unique possibility for the biological control of unwanted bacteria without having effects on other organisms such as natural flora. Medically, purified preparations of cell wall lytic enzymes could also be used as therapeutic agents either alone or in combination with classical antibiotics, particularly in external applications (Loeffler et al, 2001; Loessner, 2005). However, in the field of agriculture, research on the application of bacteriophage cell wall lytic enzymes for the control of bacteria is still limited. This review will examine the possible roles of cell wall lytic enzymes and will summarize and discuss the mechanism of infection of a bacteriophage.

\section{DISCUSSION}

\section{Cell wall lytic enzymes}

Cell wall lytic enzymes reportedly play many important roles in the life cycle of bacteria, as well as in vegetative growth, in sporulation and in germination. The roles of individual enzymes in each process have been studied by constructing mutants. One of the most cited is a study about cell wall lytic enzymes conducted on Bacillus subtilis. $B$. subtilis is the best characterized member of the Gram-positive bacteria and has been studied for more than 50 years as a model microorganism to understand its biochemistry, physiology and genetics. Its genome of 4,215,810 base pairs comprises about 4,100 protein-coding genes, with the origin of 
replication coinciding with the base numbering start point and terminus, about 2,017 kilo bases. The genome contains at least ten prophages or remnants of prophages. B. subtilis is an aerobic, non-pathogenic, endospore-forming, rod-shaped bacterium commonly found in soil, in water, and in association with plants. (Kunst et al., 1997).

The roles of cell wall degradation enzymes include peptidoglycan maturation, cell separation, motility, competence, cell expansion, cell wall turnover, protein secretion, differentiation, mother-cell lysis, and pathogenicity (Fig. 1) (Foster 1992; Blackman et al., 1998; Smith et al., 2000)

B. subtilis has more than 30 cell wall lytic enzymes. The cell wall lytic enzymes in B. subtilis are classified according to their hydrolytic bond specificity as muramidases, lytic transglycosylases, glucosaminidases, amidases, and endopeptidases (Fig. 2) (Shida and Sekiguchi 2005, Sudiarta et al., 2010a, Sudiarta et al., 2010b). In applied science, cell wall lytic enzymes as well as muramidase (lysozymes) have been utilized in a wide range of fields (biochemistry, agriculture, textiles as well as the food industry). In addition some cell wall lytic enzymes have been utilized in the field of medicine, for the control of Staphylococcus aureus, for example. The advent of $S$. aureus strains that are resistant to virtually all antibiotics has increased the need for new antistaphylococcal agents. An example of such a potential therapeutic agent is lysostaphin, an enzyme that specifically cleaves the $S$. aureus peptidoglycan, thereby lysing the bacteria (Kumar, 2008; Francius et al., 2008).

\section{Vegetative growth

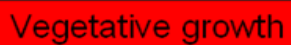

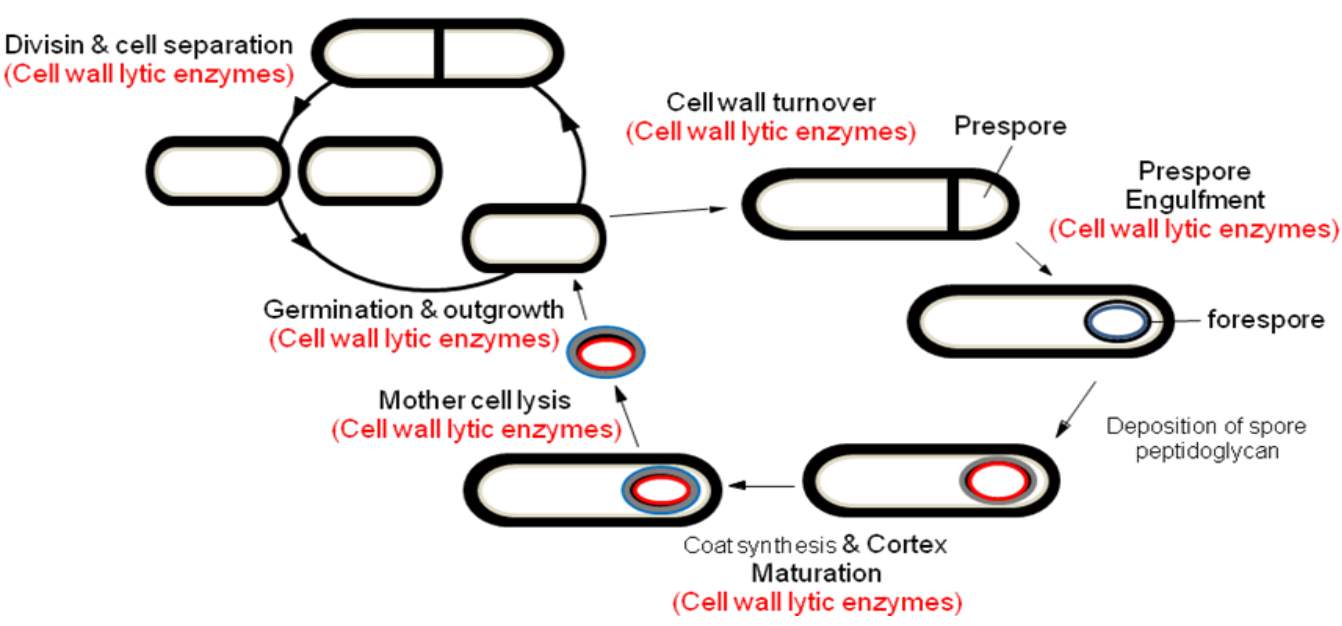

\section{Sporulation}


Figure 1. Important roles of cell wall lytic enzymes in the life cycle of Bacillus subtilis.

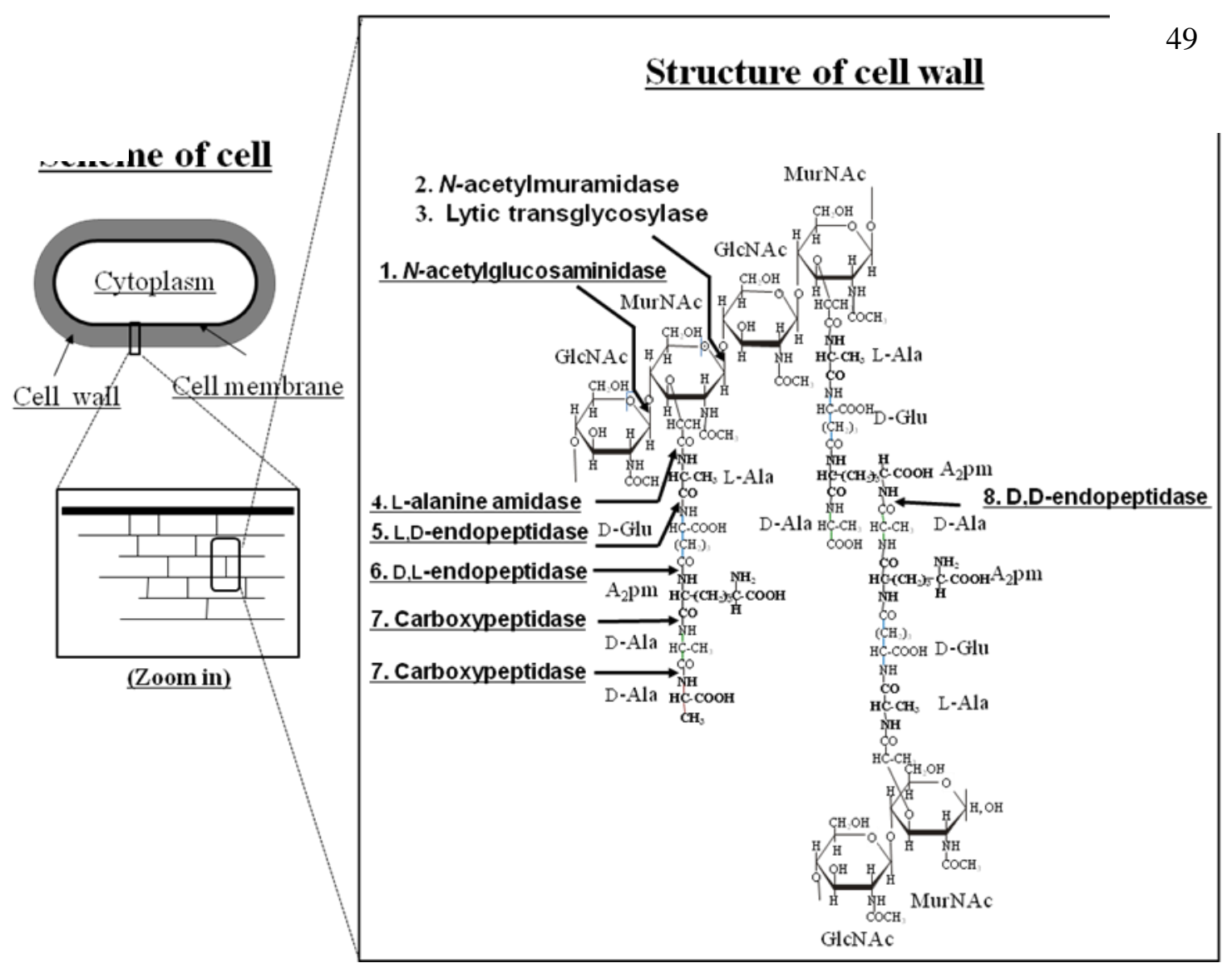

Figure 2. Structure of typical Bacillus subtilis peptidoglycan of vegetative cells. The arrows indicate hydrolytic bonds attacked by cell wall hydrolases.

The role of cell wall lytic enzymes in

\section{bacteriophages infection}

On the other hand, the cell wall lytic enzymes are also reported to play an important role in phage infection (Fig. 3). Cell wall lytic enzymes (endolysins) are phage-encoded enzymes that degrade the peptidoglycan of their hosts at the terminal stage of phage production (Loessner, 2005). The gp 13 of bacteriophage $\Phi 29$ plays an active role in cell wall lysis and is crucial in bacterial virus entry (Cohen et al., 2009).
The cycle of infection of microorganisms by bacteriophages seems

50 adsorption, insertion of nucleic roduction of nucleic acids and of bacteriophages, and host cell lysis, sequentially. However, the infection of suitable target microorganisms is very specific. Cell wall hydrolases encoded in bacteriophage genomes are involved in host cell lysis (final infection cycle) and in adsorption (facilitation of infection), the initial stage of infection (see Fig. 3) (Piuri and Hatfull, 2006). 
Recently, we reported the possible role of cell wall lytic enzymes (CwlP) in phage infection in B. subtilis (Sudiarta et $a l ., 2010 b)$. The target protein, $\mathrm{Cr}$ phage-related protein whose $\xi$ located in the SP-beta pr (Regamey and Karamata, 1998). CwIP is the largest protein, comprising 2,285 a.a. $(252 \mathrm{kDa})$, in the prophage region. Since CwlP has a phage-related minor tail domain, it is possible that the protein acts as a tail protein. Recently, Piuri and Hatfull (2006) described that gp17 of the so-called "Tape measure protein" (Tmp) is the mycobacteriophage TM4 tail protein (1,229 a.a.). The protein contains a cell wall lytic enzyme, and hydrolysis by the hydrolase facilitates efficient infection of stationary phase cells. Interestingly, Kenny et al. (2004) showed that Orf50 of bacteriophage Tuc2009 (906 a.a.) encodes tail-associated cell wall-degradation activity and is involved in infection through cell wall hydrolysis. To deliver the DNA and to break the cell wall of their hosts completely at the end of their life cycle, the bacteriophages reportedly produce cell wall lytic enzymes (Fig. 3).

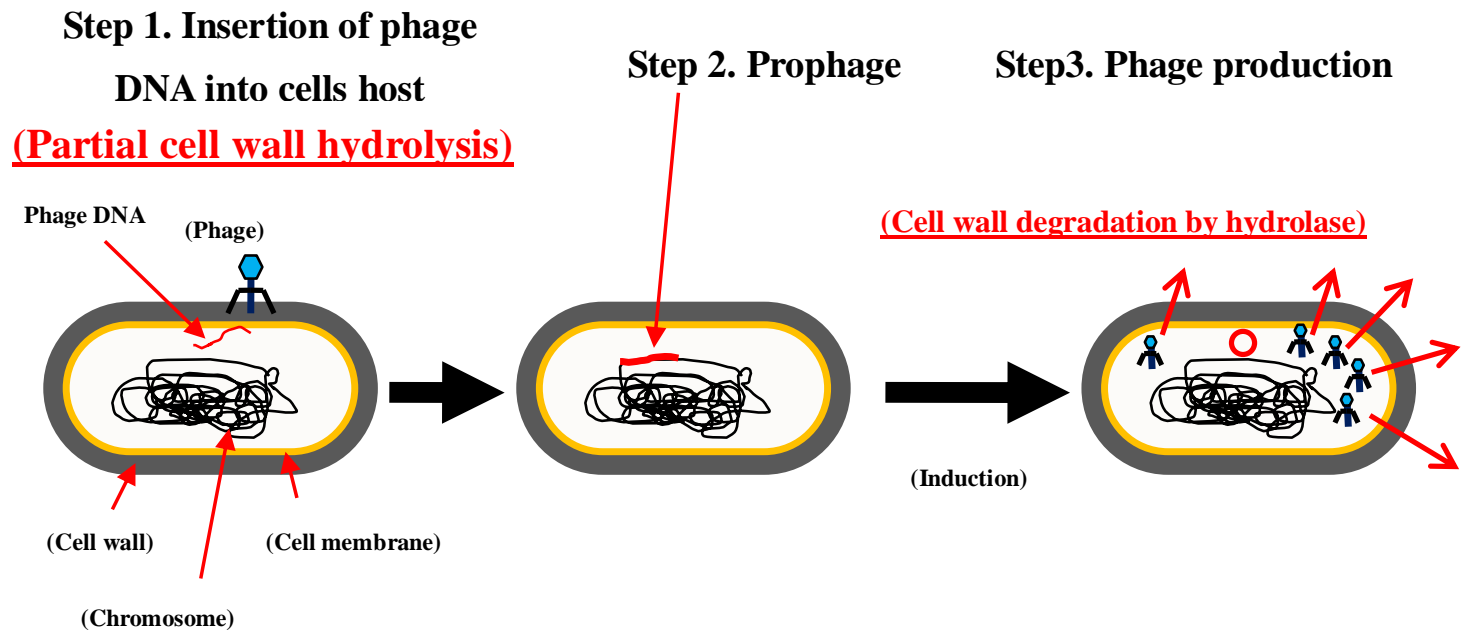

Figure 3. Life cycle of a lysogenic phage. Cell wall lytic enzymes play important roles in life cycle of lysogenic phages, especially in the periods of phage DNA insertion into the host cell (step 1) and host cell lysis after phage production (Step 2).

\section{Concluding remarks}

To support organic farming systems and sustainable agriculture the biological control of pests and diseases is an essential approach. Biological control through the harnessing of natural predator-prey relationships is an important step in reliance on environmentally damaging chemical inputs. Bacteriophages represent a viable 
alternative approach to the control of diseases caused by bacteria. Although the proper use of bacteriophages requires significant access to technology and an understanding of the specific steps of bacteriophage infection, techniques themselves are simple if one understands the role of cell wall lytic enzymes. This information will be necessary for both basic and applied study, particularly for investigation into the use of bacteriophages in agriculture areas.

\section{REFERENCES}

Blackman S.A., Smith T.J. and Foster S.J. 1998. The role of autolysin during vegetative growth of Bacillus subtilis 168. Microbiology 144: 73-82.

Cohen D.N., Sham Y.Y., Haugstad G.D., Xiang Ye, Rossmann M.G., Anderson D.L., and Popham D.L. 2009. Shared catalysis in virus entry and bacterial cell wall depolymerization. J. Mol. Biol. 387: 607-618.

Djuniadi D. 2003. Role of Industry on Integrated pest management on sustainable agriculture. Indonesian Association of Entomology Congress and Entomology Symposium VI 2003. Cipayung. 17-26. (In Indonesian Language).

Erickson, B. E. 2009. Next-generation risk assessment: EPA's plan to adopt in vitro methods for toxicity testing gets mixed reviews from stakeholders. Chemical \& Engineering News, 87: 30-33.

Foster S.J. 1992. Analysis of autolysins of Bacillus subtilis 168 during vegetative growth and differentiation by using renaturing polyacrylamide gel electrophoresis. J. Bacteriol. 174: 468-470.

Francius G., Domenech O., Mingeot-Leclercq M.P., and Dufrêne Y.F. 2008. Direct observation of Staphylococcus aureus cell wall digestion by lysostaphin. J. Bacteriol. 190(24): 7904-7909.

Kenny J.G., McGrath S., Fitzgerald G.F., and van Sinderen D. 2004. Bacteriophage tuc2009 encodes a tail-associated cell wall-degrading activity. J. Bacteriol. 186: 3480-3491.

Kumar J.K. 2008. Lysostaphin: an antistaphylococcal agent Appl. Microbiol. Biotechnol. 80: 555-561.

Kunst F., Ogasawara N., Moszer I., Albertini A.M., Alloni G., Azevedo V., Bertero M.G., Bessieres P., Bolotin A., Borchert S., Borriss R., Boursier L., Brans A., Braun M., Brignell S.C., Bron S., Brouillet S., Bruschi C.V., Caldwell B., Capuano V., Carter N.M., Choi S.-K., Codani J.-J., Connerton I.F., Cummings N.J., Daniel R.A., Denizot F., Devine K.M., Duesterhoeft A., Ehrlich S.D., Emmerson P.T., 
Entian K.-D., Errington J., Fabret C., Ferrari E., Foulger D., Fritz C., Fujita M., Fujita Y., Fuma S., Galizzi A., Galleron N., Ghim S.-Y., Glaser P., Goffeau A., Golightly E.J., Grandi G., Guiseppi G., Guy B.J., Haga K., Haiech J., Harwood C.R., Henaut A., Hilbert H., Holsappel S., Hosono S., Hullo M.-F., Itaya M., Jones L.-M., Joris B., Karamata D., Kasahara Y., Klaerr-Blanchard M., Klein C., Kobayashi Y., Koetter P., Koningstein G., Krogh S., Kumano M., Kurita K., Lapidus A., Lardinois S., Lauber J., Lazarevic V., Lee S.-M., Levine A., Liu H., Masuda S., Mauel C., Medigue C., Medina N., Mellado R.P., Mizuno M., Moestl D., Nakai S., Noback M., Noone D., O'Reilly M., Ogawa K., Ogiwara A., Oudega B., Park S.-H., Parro V., Pohl T.M., Portetelle D., Porwollik S., Prescott A.M., Presecan E., Pujic P., Purnelle B., Rapoport G., Rey M., Reynolds S., Rieger M., Rivolta C., Rocha E., Roche B., Rose M., Sadaie Y., Sato T., Scanlan E., Schleich S., Schroeter R., Scoffone F., Sekiguchi J., Sekowska A., Seror S.J., Serror P., Shin B.-S., Soldo B., Sorokin A., Tacconi E., Takagi T., Takahashi H., Takemaru K., Takeuchi M., Tamakoshi A., Tanaka T., Terpstra P., Tognoni A., Tosato V., Uchiyama S., Vandenbol
M., Vannier F., Vassarotti A., Viari A., Wambutt R., Wedler E., Wedler H., Weitzenegger T., Winters P., Wipat A., Yamamoto H., Yamane K., Yasumoto K., Yata K., Yoshida K., Yoshikawa H.-F., Zumstein E., Yoshikawa H., Danchin A. 1997.The complete genome sequence of the Gram-positive bacterium Bacillus subtilis. Nature 390, 249-256.

Lacey L.A., Frutos R., Kaya H.K., and Vai P. 2001. Insect pathogens as biological control agents: do they have a future? Biological Control 21, 230-248.

Loeffler J.M., Nelson D, Fischetti V.A. 2001. Rapid killing of Streptococcus pneumoniae with a bacteriophage cell wall hydrolase. Science 294: 2170-2172.

Loessner M.J. 2005. Bacteriophage endolysins-current state of research and application. Current opinion in microbiology 8, 480-487.

Moak M. and Molineux I.J. 2000. Role of the Gp16 lytic transglycosylase motif inbacteriophage $\mathrm{T} 7$ virions at the initiation of infection. Molecular Microbiology 37(2): 345-355.

Oates L. and Cohen M. 2009. Human consumption of agricultural toxicants from organic and conventional food. Journal of Organic Systems 4 (1): 48-57.

Piuri M., and Hatfull G.F. 2006. A 
peptidoglycan hydrolase motif within the mycobacteriophage TM4 tape measure protein promotes efficient infection of stationary phase cells. Mol. Microbiol. 62: 1569-1585.

Regamey A., and Karamata D. 1998. The $\mathrm{N}$-acetylmuramoyl-L-alanine amidase encoded by the Bacillus subtilis 168 prophage SPp. Microbiology 144: 885-893.

Shida T., Sekiguchi J. 2005. Cell wall degradation and modification hydrolases in Bacillus subtilis. Research signpost, survival and death in bacteria 117-142, ISBN: 81-7736-236-4.

Smith T.J., Blackman S.A. and Foster S.J. 2000. Autolysin of Bacillus subtilis: multiple enzymes with multiple functions. Microbiology 146: 249-262.

Sudiarta I P., Fukushima T., and Sekiguchi J. 2010a. Bacillus subtilis CwlQ (previous YjbJ) is a bifunctional enzyme exhibiting muramidase and soluble-lytic transglycosylase activities. Biochemical and Biophysical Research Communications 398: 606-612.

Sudiarta I P., Fukushima T., and Sekiguchi J. 2010b. Bacillus subtilis CwIP of the SP-beta prophage has two novel peptidoglycan hydrolase domains, muramidase and cross-linkage digesting D,D-Endopeptidase. The Journal of Biological Chemistry. 285, ( 53): 41232-41243.

Susila, W., Sumiartha K., Okajima S., and
Sudiarta P. 2005. Biological aspects studies and mass production method of the ectoparasitoid Hemiptarsenus varicornis (Girault) (Hymenoptera: Eulopidae) on Leaf Miner Play, Liriomyza sativae Blanchard (Diptera: Agromizidae). Paper Presented at the ISSAAS International Congress 2005, Hanoi Vietnam.

Sumiartha K., Susila W. and Sudiarta P. 2006. Biological study of egg rice yello stemborrer parasitoid (Tetrastichus schoenobii) (Hymenoptera: eulopidae) in the laboratory. Journal of ISSAAS 12(2): 74-75.

Supartha, I W., Bagus I G.N., and Sudiarta I P. 2005. Biodiversity of the population of Liriomyza spp. (Diptera: Agromyzidae) and Parasitoids in vegetables crop in high land area. Agritrop 24 (2): 43-51. 